\title{
Business intelligence and open data: The possibilities for the derivation of valuable information in tourism domain
}

\author{
Marija Blagojević ${ }^{1}$, Miloš Papić ${ }^{1}$, Dušan Garabinović ${ }^{2 *}$ \\ ${ }^{1}$ University of Kragujevac, Faculty of Technical Sciences Čačak, Serbia \\ ${ }^{2}$ Higher Business School of Vocational Studies "Prof. dr Radomir Bojković”, Kruševac, \\ Serbia
}

\begin{abstract}
This paper aims to introduce the concept of data analysis which could easily be implemented by anybody involved in the subject matter with basic IT knowledge and skills. The paper is divided into two parts, the first of which presents an overview of related research from two points of view: (1) publications which refer to the analysis, or the overall use of open data from the tourism domain and (2) publications which use business intelligence tools to analyse tourism data. Results indicate that there is a significant number of publications but none of them combines the two issues in the field of tourism (open data and business intelligence). The second part refers to the possibilities of using Power BI, the business intelligence tool for analysing available open data about tourism in Serbia.
\end{abstract}

Keywords: tourism, open data, business intelligence, overview, related research JEL classification: Z32, Y10, C55

\section{Poslovna inteligencija i otvoreni podaci: Mogućnosti za izvođenje vrednih informacija u oblasti turizma}

Sažetak: Ovaj rad ima za cilj da predstavi koncept analize podataka koji bi svi koji se bave predmetnom materijom s lakoćom mogli primenjivati, pri čemu im je potreban osnovni nivo IT znanja i veština. Rad je podeljen u dva dela pri čemu prvi predstavlja pregled srodnih istraživanja i to sa dve tačke gledišta: (1) pregled publikacija koje se odnose na analizu i generalno upotrebu otvorenih podataka iz oblasti turizma i (2) pregled publikacija u kojima se alati poslovne inteligencije koriste za analizu podataka u vezi turizma. Rezultati ukazuju da postoji značajan broj publikacija, ali nijedna od njih ne obrađuje istovremeno upotrebu otvorenih podataka i poslovne inteligencije u oblasti turizma. Drugi deo se odnosi na mogućnosti korišćenja Power BI alata za poslovnu inteligenciju za analizu dostupnih otvorenih podataka o turizmu u Srbiji.

Ključne reči: turizam, otvoreni podaci, poslovna inteligencija, pregled, srodna istraživanja JEL klasifikacija: Z32, Y10, C55

\footnotetext{
* dusan.garabinovic.032@gmail.com

** This study was supported by the Ministry of Education, Science and Technological Development of the Republic of Serbia, and these results are parts of the Grant No. 451-03-68/2020-14/200132 with University of Kragujevac - Faculty of Technical Sciences Čačak.
} 


\section{Introduction}

As a land of rich history, Serbia is located from a cultural point of view on the border between East and West, geographically speaking, located at a place which enables its future to be built in the direction of its tourism development potential. Serbia was ranked $83^{\text {rd }}$ in 2019 in the tourism competitiveness chart, which is an astonishing 12-position rise compared to 2017 (World Economic Forum, 2019).

Numerous spots in Serbia which have enormous tourism potential are yet to be open to a wider population of tourists. A need for marketing and promotion quality improvement is self-imposed. However, it is vital to appropriately target marketing, and for that, valid information obtained by analysing appropriate data is needed.

In the past couple of years, the world has been aiming towards opening up data in different areas of creativity. That trend has been followed by Serbia as well where data is usually opened up by public institutions. Consequently, they offer the possibility to their citizens to obtain, process and analyze them in the desired manner. Thus, public institutions achieve a higher level of transparency in their work, and the citizens are able to indirectly contribute to the important decision-making.

Collections of open data for Serbia are located at specialized portals such as Open data Portal (data.gov.rs) and are usually stored in one of the open formats such as CSV, XML, and JSON. The main characteristic of open formats is their machine-readibility, which implies that the collection of data can be automatically processed and analysed through one of the open softwares. There are many open-source business intelligence tools. In this paper, we used Microsoft Power BI. Although not entirely open, Power BI has enough free features for beginners.

One of the goals of this paper is to determine the possibility of implementing this tool to the analysis of available open data with regards to the tourist visits in Serbia in the last decade. The second important goal of this paper is an overview of related research from two perspectives: (1) publications which refer to the analysis, or the overall use of open data from the tourism domain and (2) publications in which business intelligence tools are used to analyse tourism data.

\section{Methodology}

The data on publications which deal with the subject of this paper was obtained by using the Google Scholar search engine (https://scholar.google.com/) on May 2020. The criterion for choosing the publications was the keyword in the title which directly refers to open data and business intelligence while combining terms which refer to tourist (e.g. tourism, tourist, tourists, touristic, hotel, hotels, hospitality, etc.). Dimitrovski et al. (2019) used similar methodology for conducting “A bibliometric analysis of Crossref agritourism literature”. For the realisation of the aforementioned search, the advanced search provided by Google Scholar was implemented by finding articles which include all the keywords and at least one keyword in the title. A title suitability check for the theme analysed was subsequently carried out by the authors. Papers found in journals, conference proceedings and parts of thematic collections, like books and monographs written entirely in English were used.

For the purposes of the practical part of research, the data from The Statistical Office of the Republic of Serbia were used, available at the Open Data Portal (Open Data Portal, 2020). Choosing the catering and tourism category one arrives at several collections of open data for which analysing the collection named Tourist arrivals-monthly data was chosen. Located in it is the data on the number of local and foreign tourists by months, years, and regions of the 

information in tourism domain - Hotel and Tourism Management, 2020, Vol. 8, No. 2: 113-124.

Republic of Serbia (the Region of Šumadija and Western Serbia, the Belgrade Region, the Region of Southern and Eastern Serbia and the Vojvodina Region).

The data is available in the.xls format and prior to the analysis it was necessary to perform data pre-processing. After that, a Microsoft tool for business analytics Power BI was used to carry out the analysis. The tool allows connection of different data sources and provides powerful reports. Power BI provides a possibility of integration with Excel which is significant for the users who are used to working in Microsoft environments.

\section{Results and discussion}

\subsection{Results of the search for topic-related papers}

There is a significant number of publications which deal with issues regarding open data use in the tourism field (Miele \& Mola, 2005; Cao et al., 2011; Groen et al., 2013; Cannataro et al., 2013; Longhi et al., 2014; Wu et al., 2014; McNaughton et al., 2014; Okuno, 2014; Pereira et al., 2015; Fermoso et al., 2015; Bue \& Machì, 2015; Villa, 2015; McLeod \& McNaughton, 2015; Keler \& Mazimpaka, 2016; Pesonen \& Lampi, 2016; Kršák et al., 2016; McNaughton et al., 2016; Mekhabunchakij, 2016; De Vocht et al., 2016; Li \& Hsia, 2016; Pantano et al., 2017; Urata et al., 2017; Mekhabunchakij, 2017; Sidor et al., 2017; Scorza et al., 2018; Amnur \& Meidelfi, 2018; Sedlak \& Ivanišević, 2018; Maita, 2018; Al-Ghossein et al., 2018; Ocampo \& Palaoag, 2019; Pantano et al., 2019; Duca \& Marchetti, 2019; Le \& Cao, 2020; Mountasser et al., 2020; Yochum et al., 2020), as well as the implementation of business intelligence tools for tourism data analyses (Minghetti et al., 2000; Carson et al., 2003; Zimmerman et al., 2004; Vrdoljak-Salamon et al., 2007; Salguero et al., 2008; McKnight, 2008; Galicic, 2009; Lozada et al., 2010; Vizjak et al., 2010; Custis, 2012; Crockett, 2012; Fuchs et al., 2013; Angelaccio et al., 2013; Bazdan, 2013; Sharma et al., 2013; Korte et al., 2013; Daryaei et al., 2013; Alzua-Sorzabal et al., 2014; Verma, 2014; Höpken et al., 2015; Fuchs et al., 2015; Martins et al., 2015; Baggio, 2016; Höpken \& Fuchs, 2016; Teimouri et al., 2016; Vajirakachorn \& Chongwatpol, 2017; Hyseni, 2017a; Hyseni, 2017b; Ramos et al., 2017; Mariani et al., 2018; Bilandzic \& Lucic, 2018; Chen et al., 2018; Chen, 2018; Stylos \& Zwiegelaar, 2019; Nyanga et al., 2019; Godnov \& Redek, 2019). The interesting fact is that there are no papers combining the two issues in the area of tourism (open data and business intelligence).

The following chart (Figure 1) shows a movement in the number of publications about open data and business intelligence in tourism domain.

Figure 1: Number of publications on open data and business intelligence in tourism

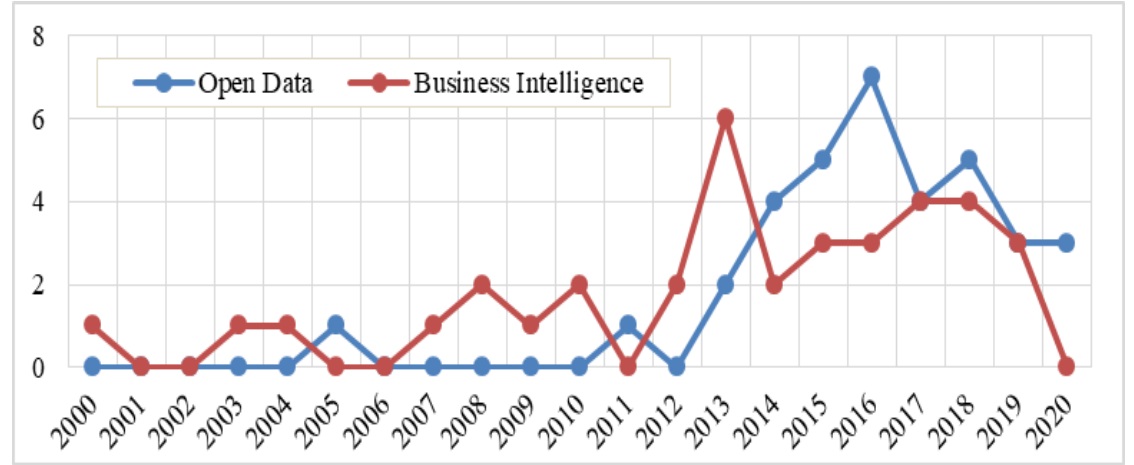

Source: Author's research 
The first paper on business intelligence in tourism was published in 2000, while the first publication on open data in tourism dates back to 2005 after which follows a five-year break. Since 2011, i.e. 2012 there is a notable increase in the number of publication about the two issues.

The following chart (Figure 2) shows the number of publications by analyzed categories for open data and for business intelligence.

Figure 2: Number of papers by categories

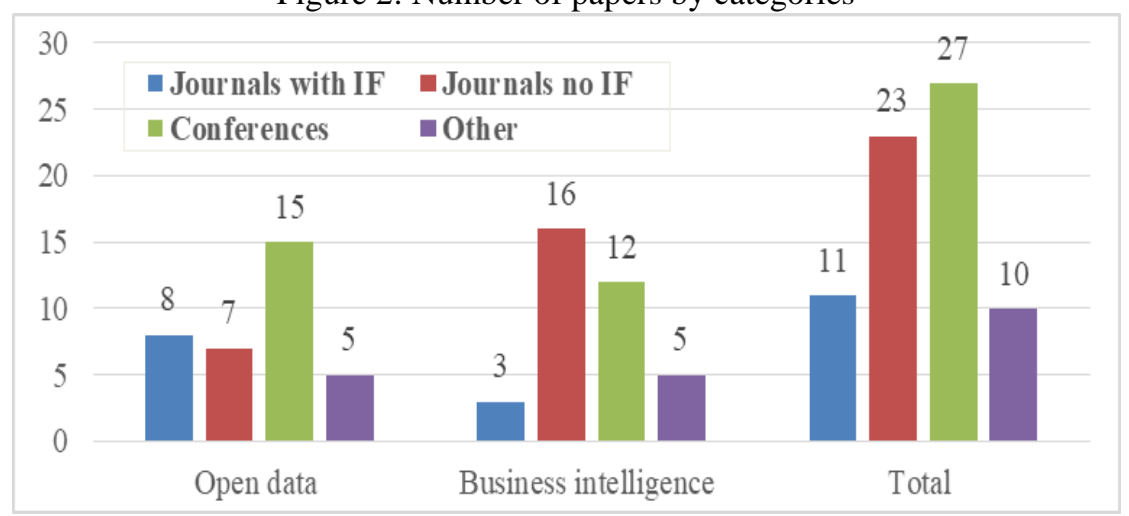

Source: Author's research

As it can be seen from Figure 2, the largest number of papers related to open data and business intelligence (total number is 71 ) was published in conference proceedings (27; $38.03 \%$ ), followed by papers published in journals which are not listed in Thomson Reuters Web of Knowledge and do not have an impact factor (23; 32.39\%), papers in journals from Web of Science database, which are a part of Thomson Reuters Web of Knowledge (11; $15.49 \%)$, and papers in other types of publications - chapters in books, monographs, etc. (10; $15.08 \%)$.

\subsection{An overview of the practical application of Power BI tools on the experimental collection of data}

The capabilities of the Power BI tool are presented in the experimental collection of data through specific analyses shown in figures 3-8. As input parameters for the analyses shown in figures 3-6, the following basic analysis results were used:

- $\quad$ an overview of the type of tourists (local, foreign);

- $\quad$ tourist visits by Serbian regions;

- $\quad$ yearly tourist visits spanning from 2010-2020;

- monthly tourist visits.

The abovementioned basic analysis were carried out but were not presented in this paper because they are extremely simple - they can be carried out in any spreadsheet software with a basic skill level. Their results indicate that in the last decade, Serbia had slightly more visits by local tourists; the most visited region was the Šumadija and Western Serbia Region; the number of tourists has been growing yearly since 2010, while in 2014 there was a slight fall. The current year (2020) has been excluded from further analysis in this paper.

Figure 3 shows an analysis of the tourist visits' decrease in 2014 according to their type (local/foreign). There was a drastic decrease in local tourists' visits, while the number of foreign tourists increased. 
Figure 3: A decrease in the number of visits in 2014 according to the type of tourist

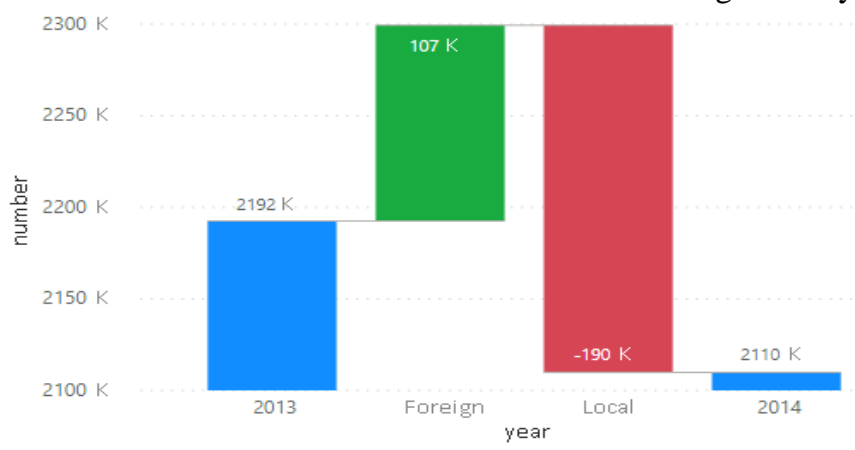

Source: Author's research

Analysing the decrease in the number of tourists' visits by region in 2014, the biggest plummet in visits is noticed in the Šumadija and Western Serbia region (Figure 4).

Figure 4: A decrease in tourist visits in 2014 according to region

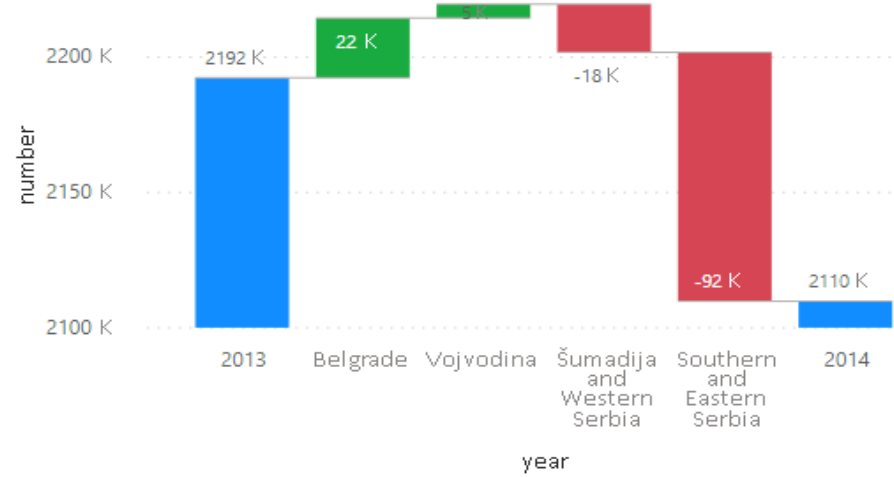

Source: Author’s research

Analysing the number of tourist visits by months in the last 10 years, it was revealed that the largest number of visits was realised during the month of August (11.6\%), and the smallest during November, where the largest decrease is noticed compared to the region (Figure 5).

Figure 5: Analysis of the decrease in visits for November according to region

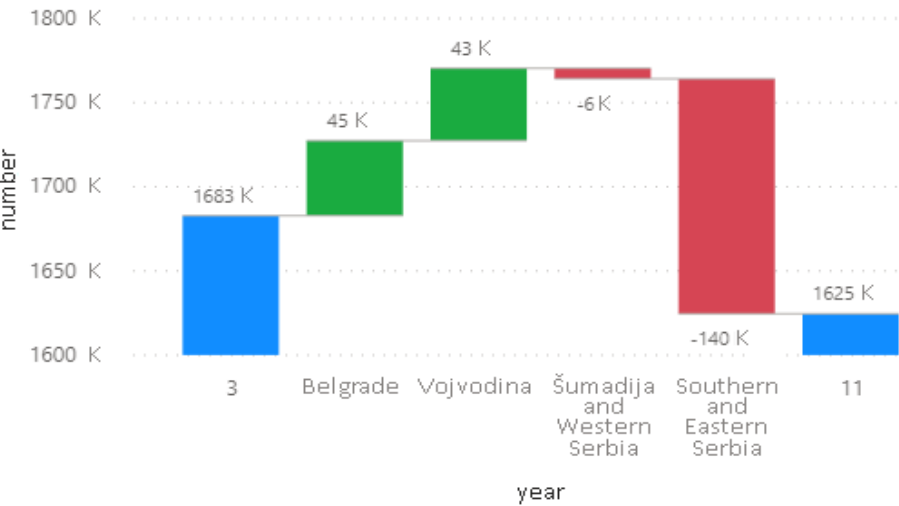

Source: Author's research 
Blagojević, M. et al. - Business intelligence and open data: The possibilities for the derivation of valuable information in tourism domain - Hotel and Tourism Management, 2020, Vol. 8, No. 2: 113-124.

The biggest plummet at the time was noted in the Šumadija and Western Serbia region. Additionally, the decrease in the number of visits was more pronounced in local tourists as opposed to foreign ones whose number was at an average increase (Figure 6).

Figure 6: Analysis of the decrease in tourist visits in November according to type

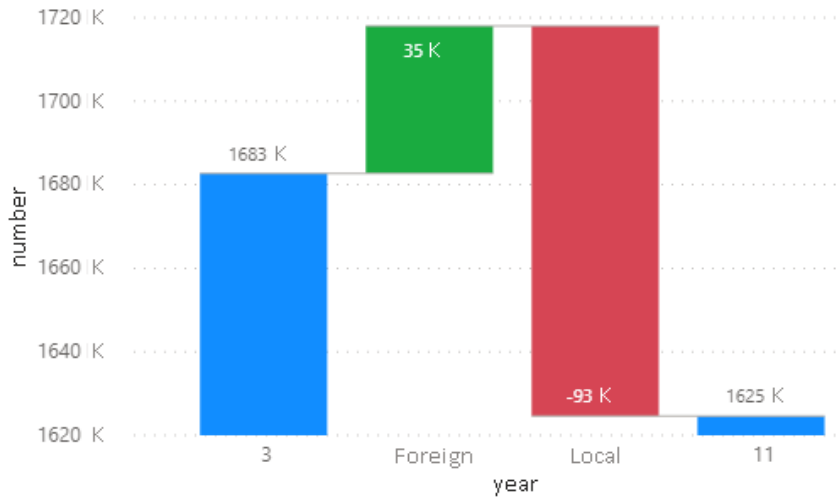

Source: Author's research

In addition to the simple analysis application which is not simple to carry out in the spreadsheet software, Power BI provides the ability for one to intuitively pose a research question to which it provides an answer. An example of the question posed and the answers given is shown in Figure 7. The research question refers to the number of visits by regions and months but with a difference compared to the month of November

Figure 7: Question asked and a given answer

\begin{tabular}{|c|c|c|}
\hline \multicolumn{3}{|c|}{$\square$ number by regian by manth difference campared ta 11} \\
\hline region & \multicolumn{2}{|c|}{ number difference campared to 11} \\
\hline 日 Šumadija and Western Serbia & 9382161 & 8913979 \\
\hline 8 & 1215552 & 747370 \\
\hline 5 & 1031336 & 563154 \\
\hline 7 & 946803 & 478621 \\
\hline 6 & 890770 & 421988 \\
\hline 10 & 758585 & 290403 \\
\hline 9 & 743224 & 275042 \\
\hline 4 & 738736 & 270554 \\
\hline 1 & 718026 & 249844 \\
\hline 2 & 675117 & 206935 \\
\hline 3 & 607784 & 139602 \\
\hline 12 & 588646 & 120464 \\
\hline 11 & 468182 & 0 \\
\hline E Belgrade & 8665720 & 8039498 \\
\hline E Sauthern and Eastern Serbia & 4167916 & 3944593 \\
\hline E Vajuadina & 4086171 & 3779328 \\
\hline Tatal & 26301968 & 24677398 \\
\hline
\end{tabular}

Source: Author's research

Given that the ultimate goal of the tourism sector is the increase of tourist visits, identifying the key factors which could lead to it is crucial for the decision makers in this field. Power Bi has an option which helps one indentify the mentioned key factors - the tool's answer to the question What influences the increase of the number of tourists is that the increase of tourist 
visits in the entire country highly depends on the number of visits in the Šumadija and Western Serbia region.

\section{Conclusion}

Considering the research goals set in this paper, and acknowledging the results obtained, conclusions are drawn from several directions:

- According to the number of similar research for both aspects of the research (35 for the use of open data in tourism and 36 for the use of business intelligence in tourism), according to the period when research data is realised, it can be said that the subject of this paper is very up-to-date and it has a grounded position in contemporary science;

- The capabilities of Power BI as a business intelligence tool are significant for analysing available open data in the tourism field. Its use is in the forefront when the information obtained after initial analysis is in need of deeper analysis. It is important to note that such analysis is impossible to be carried out in the basic skill versions of the well-known spreadsheet software.

- The literature available, data openness and free access to the business intelligence software should serve as a stimulus for the tourism sector decision makers themselves to arrive at valuable information in similar ways. As it is shown in this paper, an advanced knowledge in statistics or computer science is not necessary for data search and the use of BI software, since the tool itself has indications of artificial intelligence.

The authors' future work on this issue refers to predicting the number of Serbian tourists by year following regions and months using the data mining technique.

\section{References}

1. Al-Ghossein, M., Abdessalem, T., \& Barré, A. (2018). Open data in the hotel industry: leveraging forthcoming events for hotel recommendation. Information Technology \& Tourism, 20(1-4), 191-216. https://doi.org/10.1007/s40558-018-0119-6

2. Alzua-Sorzabal, A., Gerrikagoitia, J. K., \& Rebón, F. (2014). Using MWD: A business intelligence system for tourism destination web. Management Studies, 2(1), 62-72.

3. Amnur, H., \& Meidelfi, D. (2018). Open data of Indonesian tourism based on Android. 2018 International Conference on Applied Information Technology and Innovation (ICAITI) (pp. 36-40). Padang, Indonesia: IEEE. https://doi.org/10.1109/ICAITI.2018.8686765

4. Angelaccio, M., Basili, A., \& Buttarazzi, B. (2013). Using Geo-Business intelligence and social integration for smart tourism cultural heritage platforms. 2013 Workshops on Enabling Technologies: Infrastructure for Collaborative Enterprises (pp. 196-199). Hammamet, Tunisia: IEEE. https://doi.org/10.1109/WETICE.2013.87

5. Baggio, R. (2016). Big data, business intelligence and tourism: A brief analysis of the literature. In M. Fuchs, M. Lexhagen \& W. Höpken (Eds.), IFITT workshop on Big Data \& Business Intelligence in the Travel \& Tourism Domain (pp. 9-17). Östersund (SE): European Tourism Research Institute (ETOUR), Mid-Sweden University.

6. Bazdan, Z. (2013). Globalization, marina tourism, management and business intelligence. Economics/Ekonomija, 19(2), 237-254.

7. Bilandzic, M. \& Lucic, D. (2018). Tourism, terrorism and business intelligence Security of the Croatian economy. International Scientific Conference EKOB 2018. Conference Proceedings - "ECONOMY IN TRANSFORMED SECURITY ENVIRONMENT” (pp. 1-12). Belgrade: Center for Security, Management and International Politics (CeSMIP). 
8. Bue, A. L., \& Machì, A. (2015). Open data integration using SPARQL and SPIN: A case study for the tourism domain. In M. Gavanelli, E. Lamma \& F. Riguzzi (Eds.), Congress of the Italian Association for Artificial Intelligence (pp. 316-326). Cham: Springer. https://doi.org/10.1007/978-3-319-24309-2_24

9. Cannataro, M., Guzzi, P. H., \& Veltri, P. (2013). Using open data in health care and tourism. 2013 IEEE International Conference on Bioinformatics and Biomedicine (pp. 30-33). Shanghai, China: IEEE. https://doi.org/10.1109/BIBM.2013.6732750

10. Cao, T. D., Nguyen, Q. M., Nguyen, A. D., \& Le, T. H. (2011). Integrating open data and generating travel itinerary in semantic-aware tourist information system. iiWAS '11: Proceedings of the 13th International Conference on Information Integration and Web-based Applications and Services (pp. 214-221). https://doi.org/10.1145/2095536.2095573

11. Carson, D., Taylor, A., \& Richards, F. (2003). Delivering business intelligence for regional tourism in Australia: Analysis of the Decipher technological innovation. 5th International Conference of IT in Regional Areas (pp. 357-367). Caloundra, Central Queensland: University Publishing Unit.

12. Chen, L. F. (2018). An improved three-stage DEA as business intelligence for benchmarking luxury hotels with environmental effect. Proceedings of the 10th International Conference on Computer Modeling and Simulation - ICCMS 2018 (pp. 72-76). Sydney, Australia: Association for Computing Machinery. https://doi.org/10.1145/3177457.3177489

13. Chen, M., Lee, D., \& Ho, C. I. (2018). Business intelligence from Facebook fan pages: A case study of luxury hotels. In C. Cobanoglu, L. M. Thanh \& A. Corbaci (Eds.), Global Conference on Business, Hospitality, and Tourism Research (GLOSEARCH 2018), Conference Proceedings (pp. 61-62). Ho Chi Minh City, Vietnam.

14. Crockett, H. D. (2012). Business intelligence case study: Hotel taxes receipts. Journal of Business Case Studies (JBCS), 8(3), 265-268. https://doi.org/10.19030/jbcs.v8i3.6986

15. Custis, C. (2012). The role of business intelligence within the hospitality industry's information systems strategy: Historical concepts and future trends. Journal of Management Policy and Practice, 13(3), 82-94.

16. Daryaei, M., Shirzad, M., \& Kumar, V. (2013). Adoption of business intelligence: In hotel industry. 2013 Fourth International Conference on Computing, Communications and Networking Technologies (ICCCNT) (pp. 1-6). Tiruchengode, India: IEEE. https://doi.org/10.1109/ICCCNT.2013.6726506

17. De Vocht, L., Verborgh, R., Mannens, E., Van de Walle, R., Van den Bosch, W., Buyle, R., \& Koninckx, B. (2016). Providing interchangeable open data to accelerate development of sustainable regional mobile tourist guides. Proceedings of the 9th International Conference on Theory and Practice of Electronic Governance ICEGOV '15-16 (pp. 195-198). Montevideo, Uruguay. https://doi.org/10.1145/2910019.2910030

18. Dimitrovski, D., Leković, M., \& Joukes, V. (2019). A bibliometric analysis of Crossref agritourism literature indexed in Web of Science. Menadžment u hotelijerstvu i turizmu - Hotel and Tourism Management, 7(2), 25-37. https://doi.org/10.5937/menhottur1902025D

19. Duca, A. L., \& Marchetti, A. (2019). Open data for tourism: The case of Tourpedia. Journal of Hospitality and Tourism Technology, 10(3), 351-368. https://doi.org/10.1108/JHTT-07-2017-0042

20. Fermoso, A. M., Mateos, M., Beato, M. E., \& Berjón, R. (2015). Open linked data and mobile devices as e-tourism tools. A practical approach to collaborative e-learning. Computers in Human Behavior, 51, 618-626. https://doi.org/10.1016/j.chb.2015.02.032

21. Fuchs, M., Abadzhiev, A., Svensson, B., Höpken, W., \& Lexhagen, M. (2013). A knowledge destination framework for tourism sustainability: A business intelligence 

information in tourism domain - Hotel and Tourism Management, 2020, Vol. 8, No. 2: 113-124.

application from Sweden. Turizam: međunarodni znanstveno-stručni časopis, 61(2), 121-148.

22. Fuchs, M., Höpken, W., \& Lexhagen, M. (2015). Applying business intelligence for knowledge generation in tourism destinations - A case study from Sweden. In H. Pechlaner \& E. Smeral (Eds.), Tourism and Leisure (pp. 161-174). Wiesbaden: Springer Gabler. https://doi.org/10.1007/978-3-658-06660-4_11

23. Galicic, V. (2009). Christian Stipanovic: Business intelligence in tourism, Faculty of Tourism and Hospitality Management, Opatija, 2009. Tourism and Hospitality Management, 15(2), 307-309.

24. Godnov, U., \& Redek, T. (2019). The use of user-generated content for business intelligence in tourism: Insights from an analysis of Croatian hotels. Economic Research - Ekonomska Istraživanja, 32(1), 2455-2480. https://doi.org/10.1080/1331677X.2019.1633372

25. Groen, M., Meys, W., \& Veenstra, M. (2013). Creating smart information services for tourists by means of dynamic open data. UbiComp'13 Adjunct: Proceedings of the 2013 ACM International joint conference on Pervasive and ubiquitous computing adjunct publication. Session: Uncovering the Hidden Pulse of a City (pp. 1329-1330), Zurich, Switzerland. https://doi.org/10.1145/2494091.2499215

26. Höpken, W., \& Fuchs, M. (2016). Introduction: Special issue on business intelligence and big data in the travel and tourism domain. InfTechnol Tourism, 16, 1-4. https://doi.org/10.1007/s40558-016-0054-3

27. Höpken, W., Fuchs, M., Keil, D., \& Lexhagen, M. (2015). Business intelligence for cross-process knowledge extraction at tourism destinations. Information Technology \& Tourism, 15(2), 101-130. https://doi.org/10.1007/s40558-015-0023-2

28. Hyseni, A. (2017a). Self service business intelligence: An analysis of tourists preferences in Kosovo. UBT International Conference (pp. 107-112). Priština: University of Business and Technology in Kosovo, UBT Knowledge Center.

29. Hyseni, A. (2017b). Web scrapping and self service business intelligence: Analysis of preferences of tourists in Albania. UBT International Conference (pp. 113-119). Priština: University of Business and Technology in Kosovo, UBT Knowledge Center.

30. Keler, A., \& Mazimpaka, J. D. (2016). Safety-aware routing for motorised tourists based on open data and VGI. Journal of Location Based Services, 10(1), 64-77. https://doi.org/10.1080/17489725.2016.1170216

31. Korte, D., Ariyachandra, T., \& Frolick, M. (2013). Business intelligence in the hospitality industry. International Journal of Innovation, Management and Technology, 4(4), 429-434. https://doi.org/10.7763/IJIMT.2013.V4.435

32. Kršák, B., Sidor, C., Štrba, L., \& Mitterpák, M. (2016). Usage of linked open data for the measurement of mining tourism POIs' impact on the competitiveness of a destination: Research notes part 1. Acta Montanistica Slovaca, 21(2), 162-169.

33. Le, A. T., \& Cao, T. D. (2020). Vietnamese tourism linked open data. In S. Satapathy, V. Bhateja, B. Nguyen, N. Nguyen, \& Le DN. (Eds.), Frontiers in Intelligent Computing: Theory and Applications. Advances in Intelligent Systems and Computing, Vol. 1014 (pp. 47-56). Singapore: Springer. https://doi.org/10.1007/978-981-139920-6_5

34. Li, C., \& Hsia, P. F. (2016). The open data application on determining main types of activities to predict tourist population and ticket sales in Taiwan National Forestry Recreation Areas. Proceedings of the the 3rd Multidisciplinary International Social Networks Conference on Social Informatics 2016, Data Science 2016, MISNC, SI, DS '16 (pp. 1-4). New York, NY, United States: Association for Computing Machinery. https://doi.org/10.1145/2955129.2955151

35. Longhi, C., Titz, J. B., \& Viallis, L. (2014). Open data: Challenges and opportunities for the tourism industry. Horizons, International scientific journal, Series A, Social and 
Blagojević, M. et al. - Business intelligence and open data: The possibilities for the derivation of valuable information in tourism domain - Hotel and Tourism Management, 2020, Vol. 8, No. 2: 113-124.

humanitarian sciences, Special edition, 10(13), 15-39. https://doi.org/10.1057/9781137354358_4

36. Lozada, D., Araque, F., Castillo, J. M., Salguero, A., Delgado, C., Noda, M., \& Hernández, G. (2010). System of indicators in the innovation management: Business intelligence applied to tourism. In M. D. Lytras, P. Ordonez de Pablos, A. Ziderman, A. Roulstone, H. Maurer \& J. B. Imber (Eds.), Organizational, Business, and Technological Aspects of the Knowledge Society. World Summit on Knowledge Society - WSKS 2010. Communications in Computer and Information Science, vol. 112. (pp. 336-342). Berlin, Heidelberg: Springer. https://doi.org/10.1007/978-3-642-16324$1 \_36$

37. Maita, T. (2018). Utilization of open data via public-private cooperation in tourism sector. Fujitsu Scientific \& Technical Journal, 54(2), 9-15.

38. Mariani, M., Baggio, R., Fuchs, M., \& Höepken, W. (2018). Business intelligence and big data in hospitality and tourism: A systematic literature review. International Journal of Contemporary Hospitality Management, 30(12), 3514-3554. https://doi.org/10.1108/IJCHM-07-2017-0461

39. Martins, D., Ramos, C. M. Q., Rodrigues, J. M. F., Cardoso, P. J. S., Lam, R., Serra, F. (2015). Challenges in building a Big data warehouse applied to the hotel business intelligence. In X. Zhuang (Ed.), Recent Researches in Applied Informatics, Proceedings of the $6^{\text {th }}$ International Conference on Applied Informatics and Computing Theory (AICT '15) (pp. 110-117). Salerno, Italy: North Atlantic University Union.

40. McKnight, W. (2008). Hospitality industry business intelligence: Checking in. DM Review, 18(1), 31.

41. McLeod, M. \& McNaughton, M. (2015). Knowledge-based tourism policy formulation, as an application of open data in Caribbean tourism. In K. Adriotis (Ed.), Proceedings of the international conference on tourism (ICOT2015), From Tourism Policy into Practice: Issues and Challenges in Engaging Policy Makers and End Users (pp. 246257). London, UK: International Association for Tourism Policy.

42. McNaughton, M. L., McLeod, M. T., \& Boxill, I. (2014). Tourism open data in Jamaica: An actor network perspective. In N. Kozak \& M. Kozak (Eds.), Conference Proceedings from 3rd Interdisciplinary Tourism Research Conference (pp. 268-274). Istanbul, Turkey.

43. McNaughton, M., McLeod, M. T., \& Boxill, I. (2016). An actor network perspective of tourism open data. Tourism and Hospitality Management (Advances in Culture, Tourism and Hospitality Research, Vol. 12) (pp. 47-60). Emerald Group Publishing, https://doi.org/10.1108/S1871-317320160000012005

44. Mekhabunchakij, K. (2016). Towards modeling linked open data for decision support: An example application of Thailand tourism linked data visualization. 2016 Management and Innovation Technology International Conference (MITicon), BangSan (pp. 88-92). https://doi.org/10.1109/MITICON.2016.8025240

45. Mekhabunchakij, K. (2017). Modeling linked open data for decision support in Thailand tourism. 7th International Conference on Restructuring of the Global Economy (pp. 89-94). Oxford, UK: University of Oxford.

46. Miele, R., \& Mola, F. (2005). An open source based data warehouse architecture to support decision making in the tourism sector. Nota di Lavoro, 142, Fondazione Eni Enrico Mattei (FEEM), Milano.

47. Minghetti, V., Moretti, A., \& Micelli, S. (2000). 'Intelligent' museum as value creator on the tourism market: Towards a new business model. Information and Communication Technologies in Tourism 2000 (pp. 114-125). Vienna, Austria: Springer. https://doi.org/10.1007/978-3-7091-6291-0_11 
48. Mountasser, I., Ouhbi, B., Hdioud, F., \& Frikh, B. (2020). Ontology-based open tourism data integration framework: Trip planning platform. In M. Strydom \& S. Buckley (Eds.), AI and Big Data's Potential for Disruptive Innovation (pp. 44-70). IGI Global. https://doi.org/10.4018/978-1-5225-9687-5.ch002

49. Nyanga, C., Pansiri, J., \& Chatibura, D. (2019). Enhancing competitiveness in the tourism industry through the use of business intelligence: A literature review. Journal of Tourism Futures, 6(2), 139-151. https://doi.org/10.1108/JTF-11-2018-0069

50. Ocampo, A. J., \& Palaoag, T. (2019). Improving tourism experience in open data environment with mobile augmented reality: Needs and challenges. IOP Conference Series: Materials Science and Engineering, International Conference on Information Technology and Digital Applications (ICITDA 2018) (012005). Manila City, Philippines: IOP Publishing. https://doi.org/10.1088/1757-899X/482/1/012005

51. Okuno, T. (2014). Aggregation and application of community tourism information contents by using Linked Open Data. 2014 Joint 7th International Conference on Soft Computing and Intelligent Systems (SCIS) and 15th International Symposium on Advanced Intelligent Systems (ISIS) (pp. 579-584), Kitakyushu. https://doi.org/10.1109/SCIS-ISIS.2014.7044745

52. Open Data Portal (2020). Retrieved April 13, 2020 from https://opendata.stat.gov.rs/odata/

53. Pantano, E., Priporas, C. V., \& Stylos, N. (2017). 'You will like it!' using open data to predict tourists' response to a tourist attraction. Tourism Management, 60, 430-438. https://doi.org/10.1016/j.tourman.2016.12.020

54. Pantano, E., Priporas, C. V., Stylos, N., \& Dennis, C. (2019). Facilitating tourists' decision making through open data analyses: A novel recommender system. Tourism Management Perspectives, 31, 323-331. https://doi.org/10.1016/j.tmp.2019.06.003

55. Pereira, R. L., Sousa, P. C., Barata, R., Oliveira, A., \& Monsieur, G. (2015). CitySDK Tourism API-building value around open data. Journal of Internet Services and Applications, 6(1), 1-13. https://doi.org/10.1186/s13174-015-0039-z

56. Pesonen, J., \& Lampi, M. (2016). Utilizing open data in tourism. In I. Tussyadiah \& A. Inversini (Eds.), Information and Communication Technologies in Tourism 2016 (pp. 15). Bilbao, Spain: Springer International Publishing.

57. Ramos, C. M., Martins, D. J., Serra, F., Lam, R., Cardoso, P. J., Correia, M. B., \& Rodrigues, J. M. (2017). Framework for a hospitality big data warehouse: The implementation of an efficient hospitality business intelligence system. International Journal of Information Systems in the Service Sector (IJISSS), 9(2), 27-45. https://doi.org/10.4018/IJISSS.2017040102

58. Salguero, A., Araque, F., \& Delgado, C. (2008). Application of Business Intelligence methods for personalizing tourist services. WSEAS TRANSACTIONS on SYSTEMS, 7(10), 1176-1185.

59. Scorza, F., Pilogallo, A., \& Las Casas, G. (2018). Investigating tourism attractiveness in inland areas: Ecosystem services, open data and smart specializations. In F. Calabrò, L. Della Spina \& C, Bevilacqua (Eds.), New Metropolitan Perspectives. ISHT 2018. Smart Innovation, Systems and Technologies, vol. 100 (pp. 30-38). Springer, Cham. https://doi.org/10.1007/978-3-319-92099-3_4

60. Sedlak, O., \& Ivanišević, S. (2018). Open data and smart tourism development. In V. Bevanda \& S. Štetić (Eds.), 3rd International Thematic Monograph: Modern Management Tools and Economy of Tourism Sector in Present Era (pp. 553-563). Belgrade: Association of Economists and Managers of the Balkans, Faculty of Tourism and Hospitality, Ohrid, Macedonia. 
61. Sharma, S. K., Kumar, P., \& Gupta, V. (2013). Design of real time business intelligence system framework for tourism sector. In D. D. Gupta (Ed.), Tourism in Global Village (pp. 142-150). LAP LAMBERT Academic Publishing.

62. Sidor, C., Kršák, B. \& Štrba, L. (2017). Usage of linked open data for the measurement of mining tourism POIs' impact on the competitiveness of a destination: Research notes part 2. Acta Montanistica Slovaca, 22(4), 368-376.

63. Stylos, N., \& Zwiegelaar, J. (2019). Big data as a game changer: How does it shape business intelligence within a tourism and hospitality industry context? In M. Sigala R. Rahimi \& M. Thelwall (Eds.), Big Data and Innovation in Tourism, Travel, and Hospitality (pp. 163-181). Singapore: Springer. https://doi.org/10.1007/978-981-136339-9_11

64. Teimouri, H., Hoojaghan, F. A., Jenab, K., \& Khoury, S. (2016). The effect of managers' business intelligence on attracting foreign tourists case study. International Journal of Organizational and Collective Intelligence (IJOCI), 6(2). 1-11. https://doi.org/10.4018/IJOCI.2016040101

65. Urata, M., Ogishima, K., Usui, R., Fukuyasu, M., Endo, M., \& Yasuda, T. (2017). Creating open data sets on tourism information through citizen collaboration. Journal of Global Tourism Research, 2(1), 59-65. https://doi.org/10.37020/jgtr.2.1_59

66. Vajirakachorn, T., \& Chongwatpol, J. (2017). Application of business intelligence in the tourism industry: A case study of a local food festival in Thailand. Tourism Management Perspectives, 23, 75-86. https://doi.org/10.1016/j.tmp.2017.05.003

67. Verma, H. (2014). Business intelligence: A strategic tool for the hospitality industry. Vimarsh - A peer reviewed refereed Journal, 5(1), 59-64.

68. Villa, D. (2015). Crowdsourced heritage tourism open-data, small-data and eparticipatory practices as innovative tools in Alps cultural heritage topic: Information technology and e-tourism. In V. Katsoni (Ed.), Cultural Tourism in a Digital Era. Springer Proceedings in Business and Economics (pp. 229-230). Cham: Springer. https://doi.org/10.1007/978-3-319-15859-4_19

69. Vizjak, A., Vizjak, M., \& Ivančić, I. (2010). Using business intelligence in economics in view of tourism. In J. Perić (Ed.), 20th Biennial International congress, Tourism and Hospitality Industry 2010, New Trends in Tourism and Hospitality Management (pp. 1318-1331). Opatija: Fakultet za menadžment u turizmu i ugostiteljstvu.

70. Vrdoljak-Salamon, B., Kresic, D., \& Gatti, P. (2007). Developing of business intelligence system for tourism-BIST-the experience of Croatia. In P. Keller \& T. Bieger (Eds.), Productivity in Tourism: Fundamentals and Concepts for Achieving Growth and Competitiveness, Vol. 2, (pp. 189-200). Erich Schmidt Verlag GmbH \& Co.

71. World Economic Forum (2019). The travel \& tourism competitiveness report 2019. Retrieved July 13, 2020 from http://www3.weforum.org/docs/WEF_TTCR_2019.pdf

72. Wu, C. T., Liu, S. C., Chu, C. F., Chu, Y. P., \& Yu, S. S. (2014). A study of open data for tourism service. International Journal of Electronic Business Management, 12(3), 214-221.

73. Yochum, P., Chang, L., Gu, T., \& Zhu, M. (2020). Linked open data in location-based recommendation system on tourism domain: A survey. IEEE Access, 8, 16409-16439. https://doi.org/10.1109/ACCESS.2020.2967120

74. Zimmerman, C. A., Daigle, J., \& Pol, J. (2004). Tourism business and intelligent transportation systems: Acadia National Park, Maine. Transportation research record, 1895(1), 182-187. https://doi.org/10.3141\%2F1895-23 